\title{
軟岩の力学特性に及ぼす不連続面の影響
}

\section{EFFECTS OF JOINTS ON MECHANICAL PROPERTIES OF SOFT ROCKS}

\author{
足立 紀 尚*・林 正之** \\ By Toshihisa ADACHI and Masayuki HAYASHI
}

\section{1. 序論}

硬岩からなる岩盤の場合, 節理や層理など, 地質分離 面 (弱面) が岩盤の力学挙動を支配するから，それの影 響を把握して設計・施工に反映することが必要である. ところが, いわゆる軟岩では母岩 (intact rock) そのも のの力学特性が岩盤の力学挙動を支配する度合が, 硬岩 に比較して大きいため, 室内岩石試験結果の価值がある と考えられている.

これまで, 理想的堆積軟岩として多孔質凝灰岩である 大谷石を選び, 三軸圧縮試験を行い, 軟岩の力学特性を 調べたところ, 硬岩や土質材料の力学特性と定性的にな んら変わらないことを明らかにした ${ }^{1) \sim 4}$. この結果, 対象 とする岩石質材料特有の平均有効応力 (先行履歴応力 ${ }^{4}$ ) 以下においては, 応力ーひずみ関係がひずみ硬化一軟化型 となり, 最大強度, 残留強度ともが工学的に重要な意味 をもつことを示した. 残留強度は有効応力も体積変化も それ以上変化せず, せん断変形のみが継続する状態であ って, せん断により生じた破断面に沿ってすべっている 状態の応力をいう. 残留強度状態は破断面により力学挙 動が完全に支配されている状態であるから, 残留強度は 不連続面 (弱面) をもつ岩盤の強度としてもその最小值 に等しいと考えられる.

換言すると, 岩盤強度の下限值は岩石の残留強度に一 致するはずである.このことを模式的に示したものが 図一1 であって ${ }^{4}$, 不連続面や弱面をもつ岩盤の強度は 上限值を岩石 (intact rock) の強度に, 下限值を岩石の 残留強度にとり，一般的にはその範囲内にあることを示 したものである・

図一1 の考え方に対しては, 資料の集積や既存の不連 続面を有する供試体を用いた実験によって, 定量的に把

\footnotetext{
* 正会員 Ph.D. 京都大学助教授 防災研究所

** 正会員 富山県士木部
}

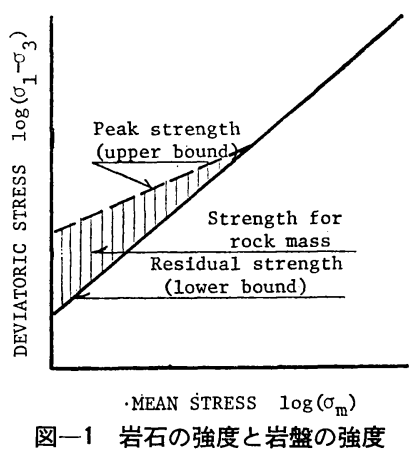

握することが必要である. 本研究はこれまでと同様, 多 孔質凝灰岩である大谷石を用い，不連続面が軟岩盤の力 学特性に及ぼす影響を考察しようとするものである。そ れは軟岩といえども, 対象とするのは地質分離面を含む 岩盤であり，不連続面の影響を解明することは重要で, かつ定性的には硬岩からなる岩盤も類似の挙動を示すで あろらから，岩盤の力学挙動をともに把握するのに役立 つ資料が求まると考えたからである.

そこで，まず岩盤が岩石と不連続面の組合せであるこ とを理想的に表現するため, 軸荷重方向に対して種々の 角度をもつ切断面をあらかじめ与えた円柱形供試体を準 備し, 側圧 $\sigma_{3}$ を変化させて三軸圧縮試験を行った.つ いで, 実験結果に基づき既存の不連続面が変形挙動や強 度特性にいかに影響するかを調べ，図一1 に示す考え方 を検討することによって, 岩石試験結果を用いて岩盤の 強度を推定する手法の確立を試みた。

切断面や弱面を与えて行うこの種の研究は多( ${ }^{5) ~ 8) . ~}$ しかし大半は強度特性, 特に最大強度に関するものであ って残留強度にまで言及したものは限られている ${ }^{7) ~}$. また，間隚を有す飽和した軟岩を対象としたものは見当 らない.さらに，材料の強度は応力ーひずみ関係におけ る単なる 1 つ特性点であるから, 応力状態のみで論ず るだけでは不十分であって, 破壊時における応力とひず みの関係も同時に考慮する必要がある. 
本研究は以上の観点に立ち, 岩盤の変形・強度特性を 室内の岩石試験によって定量的に把握する方法論を確立 することを目的とし，不連続面が力学挙動にどのように 影響するかを考察したものである.

\section{2. 大谷石のカ学特性と従来の研究}

従来の研究で大谷石の力学特性は明らかにされてい る ${ }^{1) \sim 4}$. まず，ある平均有効応力 $\left(\sigma_{m}{ }^{\prime} \fallingdotseq 50 \mathrm{~kg} / \mathrm{cm}^{2}\right)$ を 境に，異なる応力ーひずみ関係を示す．すなわち，平均 有効応力が $\sigma_{m}{ }^{\prime}=50 \mathrm{~kg} / \mathrm{cm}^{2}$ 以下であると, 過圧密状態 にある土質材料と同様の挙動を, それ以上の平均有効応 力のもとでは軽く過圧密されたか, 正規圧密状態にある 土質材料と類似の挙動を示す. より詳しく述べると, $\sigma_{m}{ }^{\prime}=50 \mathrm{~kg} / \mathrm{cm}^{2}$ 以下ではせん断に従い応力は増加して 最大強度 (peak strength) に達するが，それ以降は減少 に移り最終的には残留強度 (residual strength) に至る といら典型的なひずみ硬化-軟化型（strain-hardeningsoftening）の応力ーひずみ関係となる、このせん断過程 において, 体積は初期に圧縮を示すが, 最大強度点に至 る直前から膨張に転じる. しかしながら残留強度状態に 近づくにつれて膨張度合はしだいに減少する．ところが 平均有効応力が $\sigma_{m}{ }^{\prime}=50 \mathrm{~kg} / \mathrm{cm}^{2}$ 以上になると, せん断 とともに体積圧縮のみが生じ, 最大=残留強度状態では それ以上の体積変化は生じなくなる.

このように求まる最大強度, 残留強度とも平均有効応 力が増加するに従い大きな值をとる. また, 残留強度状 態有効応力も体積も変化せず, 単にせん断変形のみが 継続する状態であって，土質材料の critical state に対 応する ${ }^{4}$.

足立・小川4) は, 最大ならびに残留強度に対する破壊 規準は単に応力間の関係のみでは不十分で, 応力と体積 ひずみの間に成立する関係も同時に規定する必要のある ことを明らかにした，さらに, Hobbs ${ }^{9}$, Murrell ら ${ }^{10)}$ が岩石質材料に対して提唱しているべき関数型の破壊規 準を応力間の関係として適用し, 応力と体積ひずみの間 に成立する関係には土質材料の critical state に対する 平均有効応力と体積ひずみの関係を用いることによっ て, 次のような破壊条件式を与えた。

\section{（1）最大強度に対する破壊条件式}

(1) $p^{\prime}=\sigma_{m}{ }^{\prime} \leq$ 先行履歷応力の場合 $\left(q / p_{0}{ }^{\prime}\right)_{\text {peak }}=\alpha_{P}\left(p^{\prime} / p_{0}{ }^{\prime}\right)^{\beta_{P}}$ $v_{\text {peak }}=C_{s} \log _{10}\left(p^{\prime} \mid p_{0}{ }^{\prime}\right)$

(2) $p^{\prime}=\sigma_{m}^{\prime} \geq$ 先行履歴応力の場合 $\left.\begin{array}{l}\left(q / p_{0}{ }^{\prime}\right)_{\text {peak }}=\left(q / p_{0}{ }^{\prime}\right)_{\text {residual }} \\ v_{\text {peak }}=C_{c} \log _{10}\left(p^{\prime} / p_{0}{ }^{\prime}\right)-v_{0 P}\end{array}\right\}$

\section{（2）残留強度に対する破壊条件式}

(1) $p^{\prime}=\sigma_{m}{ }^{\prime} \leq$ 先行履歴応力の場合

$\left(q / p_{0}{ }^{\prime}\right)_{\text {residual }}=\alpha_{R}\left(p^{\prime} / p_{0}{ }^{\prime}\right)^{\beta_{R}}$ $\left.v_{\text {residual }}=C_{R} \log _{10}\left(p^{\prime} / p_{0}{ }^{\prime}\right)-v_{0 R}\right\}$

(2) $p^{\prime}=\sigma_{m}{ }^{\prime} \geq$ 先行履歷応力の場合

$$
\left.\begin{array}{l}
\left(q / p_{0}{ }^{\prime}\right)_{\text {residual }}=\alpha_{R}\left(p^{\prime} / p_{0}{ }^{\prime}\right)^{\beta_{R}} \\
v_{\text {residual }}=C_{c} \log _{10}\left(p^{\prime} / p_{0}{ }^{\prime}\right)-v_{0 P}
\end{array}\right\}
$$

式中では, $p^{\prime}=\sigma_{m}{ }^{\prime}=\left(\sigma_{1}{ }^{\prime}+2 \sigma_{3}{ }^{\prime}\right) / 3$, 平均有効応力 $q=$ $\left(\sigma_{1}{ }^{\prime}-\sigma_{3}{ }^{\prime}\right)$, 軸差応力 $p_{0}{ }^{\prime}=$ 単位圧力 $=1 \mathrm{~kg} / \mathrm{cm}^{2}, \alpha_{P}, \beta_{P}$, $\alpha_{R}, \beta_{R}, C_{s}, C_{c}, C_{R}, v_{0 P}$ は材料定数 であって, 大谷 石に対するこれらの值は, 図一2，3 中に示している.

この破壊条件式は図一2，3 の実験事実に基づき求め られたものである.なお, 先行履歴応力は先に述べたと 抢り，図一2 に示す最大強度線と残留強度線の交わる点 の応力状態と定義づけており，それ以上の拘束圧下では 最大強度と残留強度が等しくなる.

Einstein と Hirschfeld ${ }^{8)}$ は石高を用い，あらかじめ 弱面を入れた供試体を準備して三軸圧縮試験と直接せん 断試験を行った. 彼らは直応力とせん断応力の関係にお いて, 岩石の変形・強度特性に与える不連続面の影響を 論じ, 図一4 に示す A, B, C の 3 領域で力学挙動がい

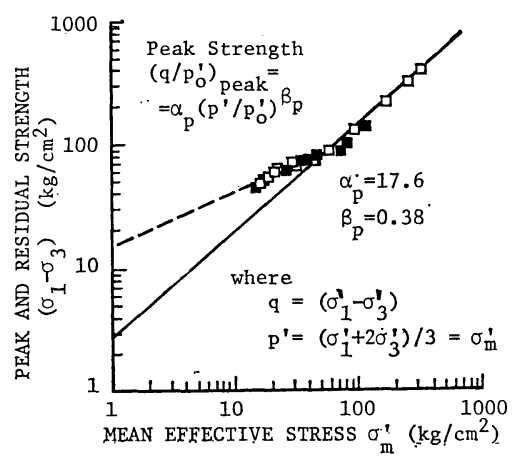

(a) 応力関 係

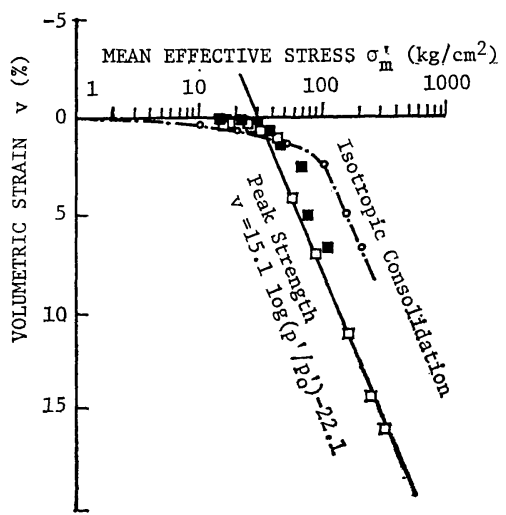

（b）平均有効応力-体積ひずみ関係

図一2 最大強度 (先行履歴応力以上では 残留強度に等しい) 


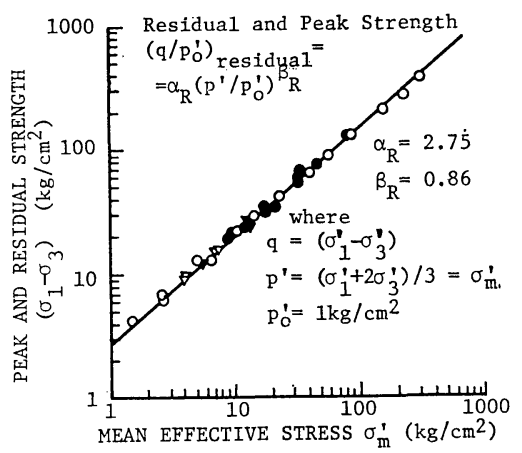

(a) 応力関 係

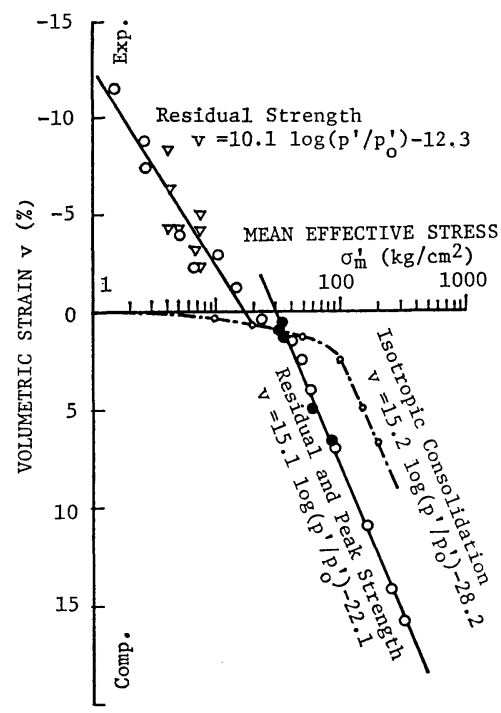

（b）平均有効応力-体積ひずみ関係

図一3 残留強度 (先行履歴応力以上では 最大強度に等しい)

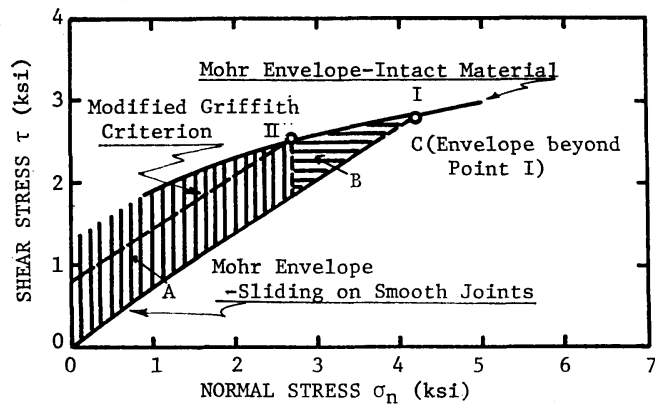

図一4 切断面を有する材料挙動の拘束圧依存性

かに変化するかを次のようにまとめている，

$\mathbf{A}$ 領域：既存の不連続面に沿って破壊が生じるが，そ れが不可能であると内部構造自体の破壊となり，既存の 不連続面に沿う破壊より大きな強度を発揮する。

B領域：破壊 すべり面が，既存の不連続面と交わら ず，不連続面の角度がある範囲内にあればそれに沿って 破壊するが，一般的には内部構造の破壊となる。この領
域はぜい性破壊から延性破壊への遷移領域である。

$\mathbf{C}$ 領域：材料は延性的挙動を示し, 強度は不連続面の 影響を受けず，単一の破壊包絡線となる.

A, B 両領域に区分する必要はないと考えるが，参考 のためにここに示した.

\section{3. 試料と実験方法}

試料はこれまでと同様，第 3 紀堆積の多孔質凝灰岩で ある通称大谷石を用いた ${ }^{1) \sim 4}$. この理由は本試料が比較 的均質であって，堆積軟岩の理想材料とみなし得るから である. その物理諸量は表一1 に示すとおりである.

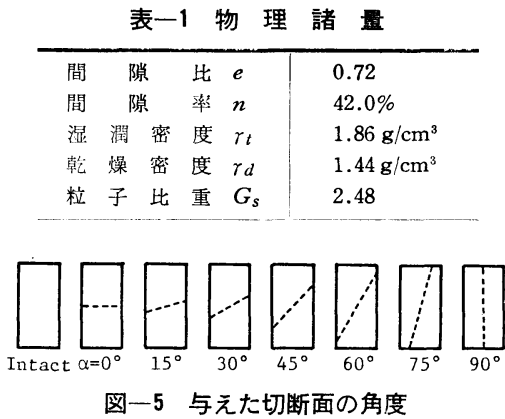

供試体は直径 $5 \mathrm{~cm}$, 高さ $10 \mathrm{~cm}$ の円柱形である. 本 研究においては図一5に示すように軸荷重（最大主応力 $\sigma_{1}$ ）作用面と種々の角度 $\alpha$ をつつ切断面をダイヤモンド カッターにより入れた供試体と切断面のない岩石 (intact rock）を用いた。したがって，切断面は平坦で滑らかな 面である. なお，水で飽和した軟岩を対象とすることか ら, 供試体を容器内に水浸させ 24 時間以上サクション をかけて脱気を行い飽和させた。

実験は $3 \mathrm{~kg} / \mathrm{cm}^{2}$ のバックプレッシャーと有効側圧 $\sigma_{3}{ }^{\prime}=1,3,5,6,10,20 \mathrm{~kg} / \mathrm{cm}^{2}$ を作用させ，ひずみ制御 による排水せん断試験である，供試体をセットする際， 供試体表面のくぼみや，切断面の空隚，排水用のナイ口 ンメッシュとゴム膜の間に残る気泡を抜くため，ゴム膜 をかぶせ上端部の０リングをセットしない状態で供試体 が水浸する程度まで水を張ってサクションを作用させ， 飽和度の向上を図った. その後, 所定の側圧で 24 時間 等方圧密して,ひずみ速さ一定 $\left(\dot{\varepsilon}_{1}=0.027 \% / \mathrm{min}\right)$ の三 軸圧縮せん断を行った。 なお，用いた載荷装置はボール ジャッキ（30 t 容量）によるもので，かつひずみ速さ一 定の条件はせん断中ほぼ満足されるから，剛性試験と考 えてよい.

また，実験した供試体の本数は各側圧，各角度につい て各 1 本である.

有効側圧 $\sigma_{3}{ }^{\prime}$ が $20 \mathrm{~kg} / \mathrm{cm}^{2}$ 以下であると, 大谷石は最 大強度に達する直前に，1 つのせん断面が生じ，以後そ 
の面に沿ってすべり破壊に 至るから, 最大強度以降の 态力の算定は堀 ${ }^{11}$ による断 面補正方法によった。つま り，図一6 に示すように角 度 $\alpha$ の破断面が生じた場 合, 有効断面積 $A_{e}$ はひす みの増大とともに減少し, 軸ひずみが $\varepsilon_{1}$ のときに次 式で与えられることにな る.

$$
A_{e}=\frac{D^{2}}{4}(\theta-\sin \theta)
$$

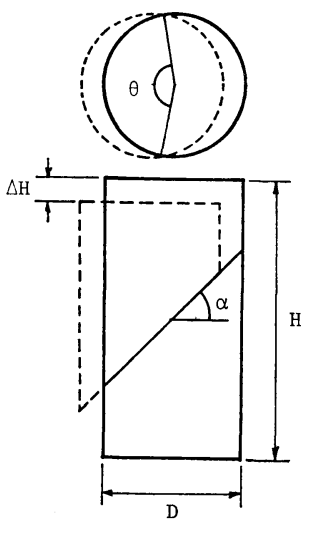

図一6 断面補 正
ここに, $D$ は供試体の直径, $\theta$ は 図一6 に示寸角度で, 次式のように与えられる.

$$
\cos \frac{\theta}{2}=\frac{\Delta H}{D \tan \alpha}\left(=\frac{\varepsilon_{1} H}{D \tan \alpha}\right)
$$

あるいは次のようにも書き改められる。

$$
\theta=2 \cos ^{-1}\left(\frac{\varepsilon_{1} H}{D \tan \alpha}\right)
$$

なお, 破断面が生じるまでは次式による通常の断面補正 を行う.

$$
A_{e}=A_{0} /\left(1-\varepsilon_{1}\right)
$$

式中で, $A_{e}$ : 有効断面積, $A_{0}$ : 初期断面積, $\varepsilon_{1}$ : 軸ひ ずみ，他は図一6に示してある.しかしながら，破断 面がどの時点でいかなる角度をもって発生するかを決定 するのは困難であるため, 式 (5) による補正は最大強度 点以降に適用し, 破断面の角度は実験終了後測定した値 を用いた。

\section{4. 切断面を有する軟岩の力学挙動}

\section{（1）切断面の角度ならびに拘束圧と破壊形態}

最大主応力作用面と種々の角度をもつ切断面を与え， 切断面の存在とその角度が岩石と切断面の組み合わさっ た 1 つ集合体に与える影響を解明することが, 本研究 の目的である. まず，切断面をもつ供試体がどのように 破壊するかをみてみよう。

図一7 は実験の結果による破壊形状を示しており，図 中の点線は既存の切断面を実線は破壊すべり面を与えて いる.たとえば，CD-1 は $1 \mathrm{~kg} / \mathrm{cm}^{2}$ の有効側圧で等方 圧密排水せん断試験を行ったことをそれぞれ示してい る.

この図から低側圧 $\left(\sigma_{3}{ }^{\prime} \leq 10 \mathrm{~kg} / \mathrm{cm}^{2}\right)$ の場合, $\alpha=0^{\circ}$, $15^{\circ}, 30^{\circ}$ の切断面を有する供試体は切断面をもたないも のと同様，切断面に関係のない約 $60^{\circ}$ の破断面が生じて

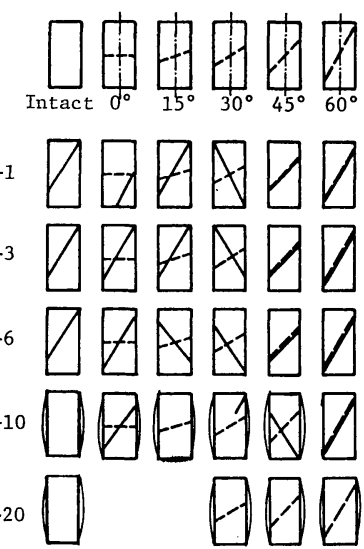

図一7 供試体中に生じた破壊すべり面と既存の切断面

破壊するが，他方， $\alpha=45^{\circ}, 60^{\circ}$ の場合に は 既存の切断 面に沿った破壊であることがわかる。なお， $\alpha=75^{\circ}, 90^{\circ}$ の試料は CD-5 の場合のみ実験を行った. 結果は新た に約 $60^{\circ}$ の破断面が生じ破壊したが図一7 には示してい ない.ところが $\alpha=45^{\circ}$ では $10 \mathrm{~kg} / \mathrm{cm}^{2}$ 以上， $\alpha=60^{\circ}$ で は $20 \mathrm{~kg} / \mathrm{cm}^{2}$ と側圧 $\sigma_{3}{ }^{\prime}$ が高くなると, 他の角度の場 合と同様に既存の切断面に関係なく $60^{\circ}$ に近い新たな破 断面が生ずるか，ビヤ樽形のせん断破壊を示すようにな る. すなわち, 大谷石の場合, 有効側圧 $\sigma_{3}{ }^{\prime}=20 \mathrm{~kg} / \mathrm{cm}^{2}$ に対する最大強度時の応力状態 (平均有効応力) は先行 履歴応力 $\left(\sigma_{m}{ }^{\prime} \fallingdotseq 50 \mathrm{~kg} / \mathrm{cm}^{2}\right)$ に近く, 力学挙動が切断面 (弱面)の有無に影響されない状態に至ったといえる.

\section{（2）応力ーひずみ関係}

先に述べたように, 大谷石は, 有効平均応力 $\sigma_{m}{ }^{\prime}=50$ $\mathrm{kg} / \mathrm{cm}^{2}$ を境に，それ以下ではひずみ硬化-軟化型の応力 一ひずみ関係を，それ以上ではひずみ硬化型の関倸を示 す. 図一8〜11 は実験により求まった応力ーひずみ関係 を (a) に軸差応力 $\left(\sigma_{1}{ }^{\prime}-\sigma_{3}{ }^{\prime}\right)$ ～偏差ひずみ $e_{1}\left(=\varepsilon_{1}-v / 3\right)$ 関係，(b) に体積ひずみ $v$ 偏差ひずみ関係としてそれ ぞれ示している. なお，図一8 は, 有効側圧 $\sigma_{3}{ }^{\prime}=1 \mathrm{~kg} /$ $\mathrm{cm}^{2}$ (CD-1 と表示), 図一9 は $5 \mathrm{~kg} / \mathrm{cm}^{2}$, 図一10 は 10 $\mathrm{kg} / \mathrm{cm}^{2}$, 図一11 は $20 \mathrm{~kg} / \mathrm{cm}^{2}$ の結果である. 図から得 られる知見をまとめると以下のようになる.

(1) 切断面の角度が $\alpha=0^{\circ}, 15^{\circ}, 30^{\circ},\left(90^{\circ}, \mathrm{CD}-5\right)$ の 場合, CD-1〜CD-20すべてにおいて, intact rock と同 様でほぼ等しい応力ーひずみ関係を示す。

(2) 一方, 切断面の角度が $\alpha=45^{\circ}, 60^{\circ},\left(75^{\circ}, \mathrm{CD}-5\right)$ の場合, 拘束圧の大小が応力ーひずみ関係に影響する. $45^{\circ}$ についてみると, 側圧が $10 \mathrm{~kg} / \mathrm{cm}^{2}$ 以下であっても ひずみ硬化-軟化挙動を示すが，最大強度時の偏差ひず み $e_{1}$ は $4 \%$ と, 他の場合の $1 \%$ 前後に比較して大き なひずみ状態で生じている， $\alpha=60^{\circ}$ の場合はひずみ硬 化型の単調な応力ーひずみ関係となり, 最大強度は残留 


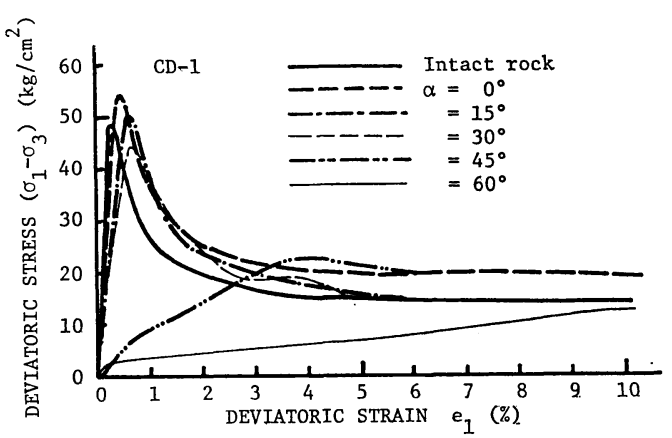

(a) 軸差応力-偏差ひずみ

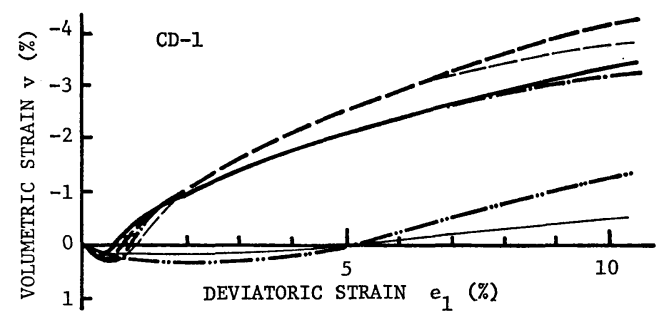

（b）体積ひずみー偏差ひずみ

図一8 応力ーひずみ関係 (CD-1)

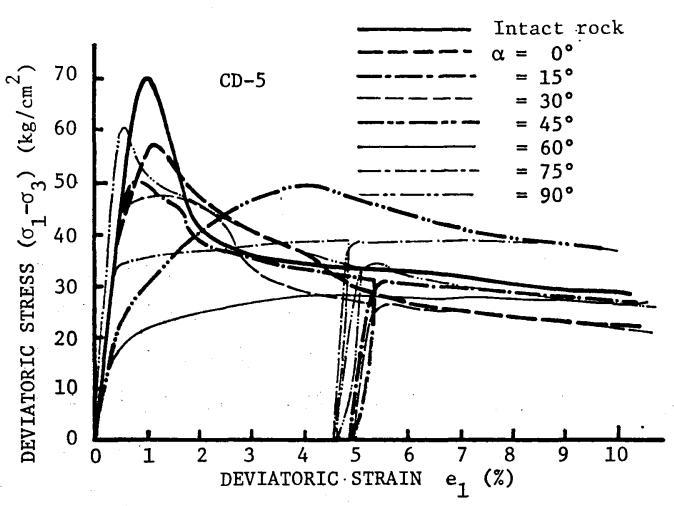

（a）軸差応力-偏差ひずみ

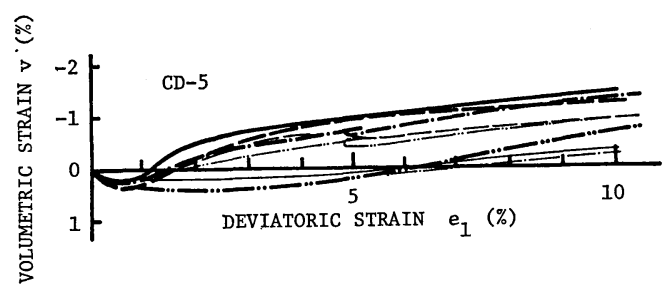

（b）体積ひずみー偏差ひずみ

図一9応力ーひずみ関係 (CD-5)

強度に等しい。

(3) 側圧が $20 \mathrm{~kg} / \mathrm{cm}^{2}$ になると，図一11(a) のように 弾-完 全塑性型といってよい応力ーひずみ関係を示し, 既存の弱面が力学挙動に影響を与えなくなる.

(4) 残留強度 $\left(e_{1} \fallingdotseq 10 \%\right.$ 近傍の軸差応力值) は側圧 が等しいと切断面の有無や切断面の角度に関倸なくほぼ

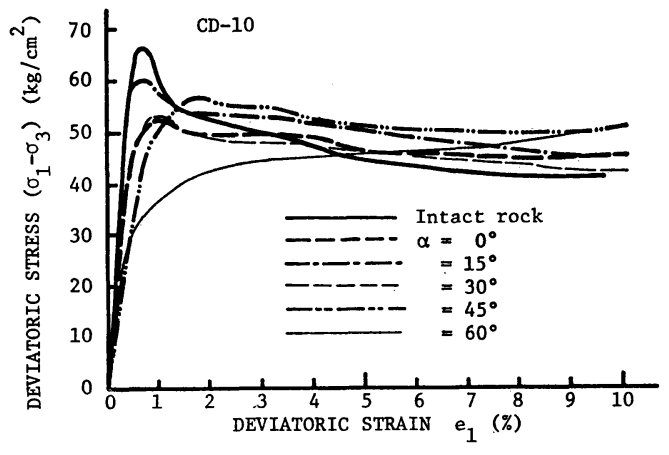

(a) 朝差応力-偏差ひずみ

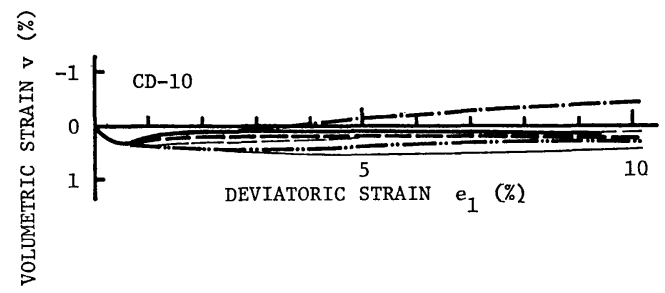

（b）体積ひずみ一偏差ひずみ

図-10 応力-ひずみ関係 (CD-10)

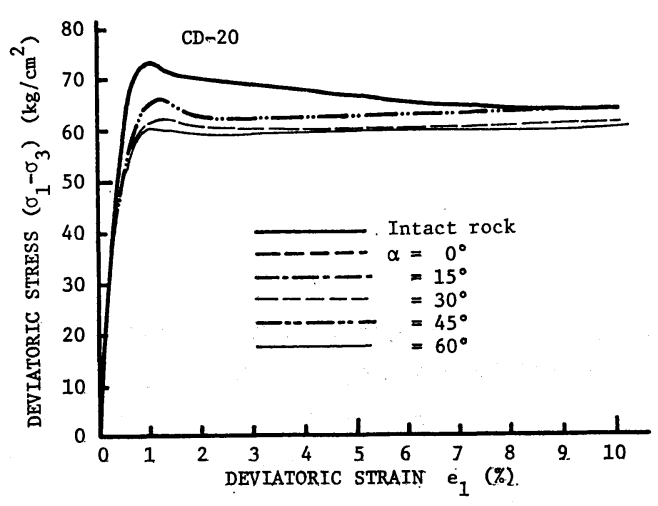

(a) 軸差応力-偏差ひずみ

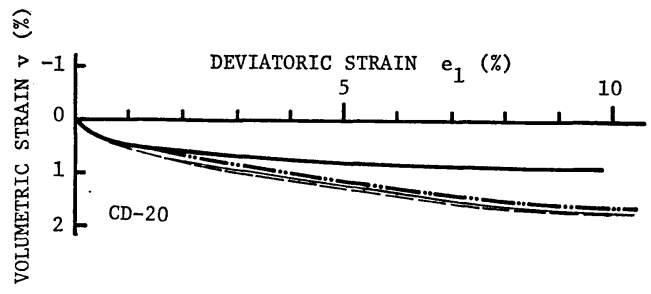

（b）体積ひずみ一偏差ひずみ

図一11 応力ーひずみ関係 (CD-20)

等しい值となるが，側圧が $10 \mathrm{~kg} / \mathrm{cm}^{2}$ 以下の $\alpha=45^{\circ}$ (75, CD-5) の残留強度は他の場合の值に比較して大き い. これは図一7に示したように, $\alpha=45^{\circ}$ の切断面に沿 うすべり破壊であるから，そのせん断抵抗は $\tau=\left(\sigma_{1}-\right.$ $\left.\sigma_{3}\right) \sin \varphi / 2\left(\varphi\right.$ : すべり面の角度) に $\varphi=\alpha=45^{\circ}$ を代入し て求まり, $\varphi \fallingdotseq 60^{\circ}$ で計算される他の場合の值より 
$2 / \sqrt{3} \fallingdotseq 1.15$ だけ大きな值をとることによるものと考 えられる。

(5) 側圧が $5 \mathrm{~kg} / \mathrm{cm}^{2}$ 以下であるとせん断中の体積変 化は切断面の影響を受ける. 寸なわち, $\alpha=0^{\circ}, 15^{\circ}, 30^{\circ}$, $\left(90^{\circ}, \mathrm{CD}-5\right)$ の場合は intact rock と同様, せん断過程 で大きな体積膨張（ダイレイタンシー）が生じるが, $\alpha=45^{\circ}, 60^{\circ}$, (75, CD-5) に抒いてはダイレイタンシー 量が前者に比較して小さい. しかし，側圧が大きくなる とこの差異が認められなくなる.

(6) 以上を総括すると intact rock, 切断面の角度 $\alpha=$ $0^{\circ}, 15^{\circ}, 30^{\circ},\left(90^{\circ}, \mathrm{CD}-5\right)$ の場合と $\alpha=45^{\circ}, 60^{\circ},\left(75^{\circ}\right.$, CD-5）とでは前者が新たにせん断面が生じ破壊するの に対し，後者は既存の切断面に沿うすべり破壊となり異 なる挙動を示すことがわかる. しかし，平均有効応力が 先行履歴応力 $\left(\sigma_{m}{ }^{\prime}=50 \mathrm{~kg} / \mathrm{cm}^{2}\right)$ に近づくにつれ, 弱面 の影響は消滅する.

(7) CD-5 の場合には，図一9に示すと打り偏差ひず みが約 $5 \%$ に達したところで除荷一再載荷を行った．こ の過程における応力ーひずみ関倸は，初期せん断時の応 力ーひずみ関係に比較して立ち上がりの勾配がやや小さ いが弾性的挙動であるといえる.このことは, 切断面

（弱面）を有する供試体も，せん断により新たに破断面 が生じたものも，除荷一再載荷過程における弾性係数は intact rock の弹性係数よりは小さいが，オーダー的に は同程度の値をとると考えてよいことを示している。

\section{（3）切断面の弾性係数に与える影響}

切断面によって, せん断弾性係数 $G$ と体積弾性係数 $K$ がいかに影響されるかを調べてみた. 種々の角度を もつ不連続面が内在すると材料の力学特性には方向性 （異方性）が現れる.しかしながら，ここでは材料は等 方性材料と仮定し, その結果求まる材料定数の值の差と して異方性が現れるものと考えて議論を進めることにす る.

軸対称三軸試験の場合, せん断弹性係数 $G$ は軸差応 力 $\left(\sigma_{1}{ }^{\prime}-\sigma_{3}{ }^{\prime}\right)$ 偏差ひずみ $e_{1}$ 関係の初期の勾配から次 式によって決定できる.

$$
G=\left(\sigma_{1}-\sigma_{3}\right) / 3 e_{1}
$$

体積弾性係数は平均有効応力 $\sigma_{m}{ }^{\prime} \sim$ 体積ひずみ $v$ 関 係の勾配より次式で求められる.

$$
K=\sigma_{m}{ }^{\prime} / v
$$

図一12,13 は, このようにして求めたせん断弹性係 数 $G$ と体積弾性係数 $K$ を intact rock の弾性係数 $G_{c}$, $K_{c}$ でそれぞれ規準化し，角度をパラメーターに有効側 圧 $\sigma_{3}{ }^{\prime}$ ごとに示したものである. なお, 図中の線は変化 の様子を端的に示すために引いたものである。

図から求まる結論は以下のと㧍りである.
(1) せん断弾性係数は切断面の角度により変化し, $\alpha=45^{\circ}$ で最小值となる. しかし，側圧が大きくなると 切断面の存在による差異はみられなくなる. $\alpha=45^{\circ}$ で $G$ が最小值をとる理由は， $\alpha=45^{\circ}$ で残留強度が大きな 值をとることと表裏をなすものである.すなわち供試体 中の最大せん断応力は常に $45^{\circ}$ 面内に作用するから， $=45^{\circ}$ に弱面があるとせん断初期に最も変形しやすく, せん断弾性係数は小さな值をとるものと考えられる.

(2) CD-1 を例外とすれば体積弾性係数 $K$ は intact rock の值に比較して小さな值となっているものの, 切断 面の影響は $G$ に比較して小さい.

(3) 図中に黒丸で示寸值 は, 図一9 の除荷-再載荷過

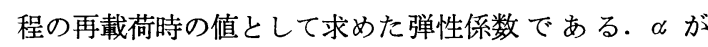
$30^{\circ}$ 以下では, 白丸で表す初期の弾性係数に比較して小 さい值となるが,オーダー的には変わらない，

(4) ヤング率 $E$, ポアソン比 $ン$ は $G, K$ と次の関係 にある。

$$
E=\frac{9 K G}{(3 K+G)}, \quad \nu=\frac{(3 K-2 G)}{2(3 K+G)}
$$

ここには示さないが，これから求めたヤング率はせん断 弾性係数 $G$ と同様に切断面の角度に影響される. しか し, ポアソン比は体積弾性係数 $K$ と同様, 切断面の影 響度合は小さく, intact rock の值よりやや大きい 0.1 $\sim 0.2$ の值となる.

\section{（4）切断面の最大ならびに残留強度に及ぼす影響}

図一8〜11 の応力-ひずみ関係から，最大強度が切断 面の角度によって異なる值をとることは明らかである. このことをより明確に示すために図一14 を準備した。 図中の白丸 $q=\left(\sigma_{1}{ }^{\prime}-\sigma_{3}{ }^{\prime}\right)$ によりそれぞれ示している.なお，すべて の值はその側圧における intact rock の最大強度 $q_{c}$ て 規準化しており，点線で示寸円弧は intact rock の残留 強度である。

図から得られる知見をまとめると以下のようである。

(1) 最大強度は切断面の角度により影響を受け， $\alpha=$ $60^{\circ}$ で最小值を示すが, その值は intact rock や他の角 度の切断面をもつ供試体の残留強度にほぼ等しい. しか し, 側圧が増加すると, 切断面の有無に関係なく, 最大 強度と残留強度がほぼ等しい值をとる。

(2) 残留強度は intact rock の残留強度と変わらず, 切断面の角度に影響されない。ただし， $\alpha=45^{\circ}$ の残留 強度は前述した理由によって, 他の角度の残留強度に比 較して大きな值をとる。

切断面の角度が最大強度に及ぼす影響を Mohr の応力 円の包絡線を用いて検討してみる. 図一15(a) は intact rockの最大強度に対するMohrの応力円と包絡線を 


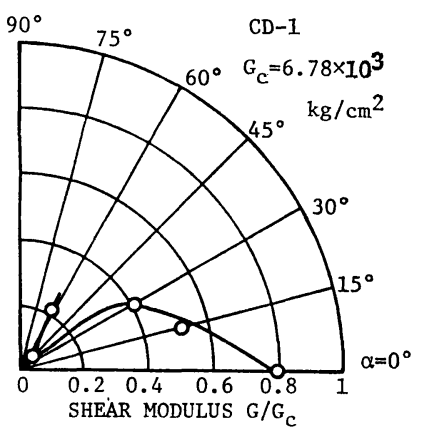

(a) $\mathrm{CD}-1$

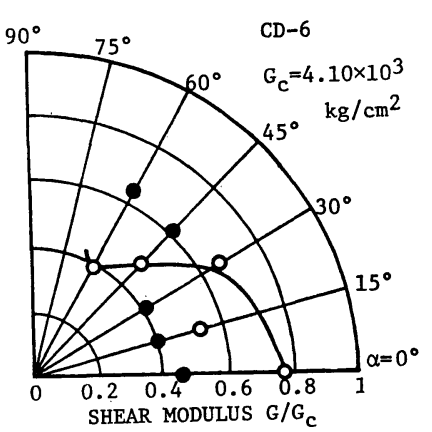

(d) $\mathrm{CD}-6$

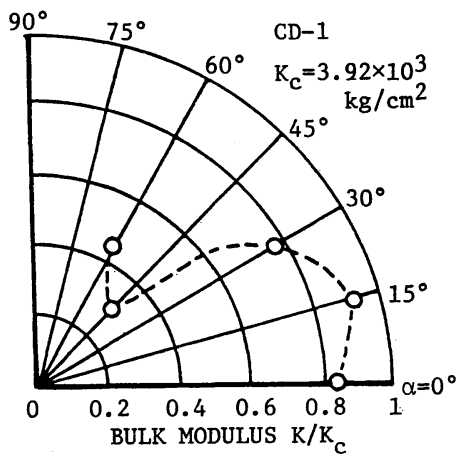

(a) $\mathrm{CD}-1$

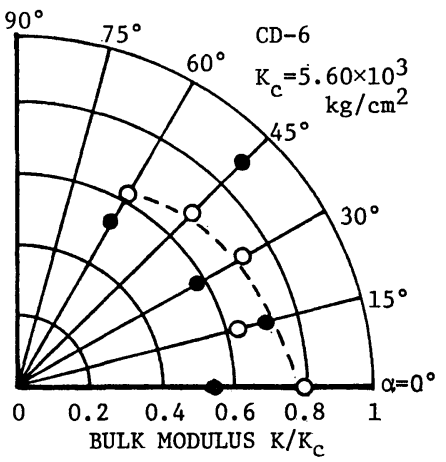

(d) $\mathrm{CD}-6$

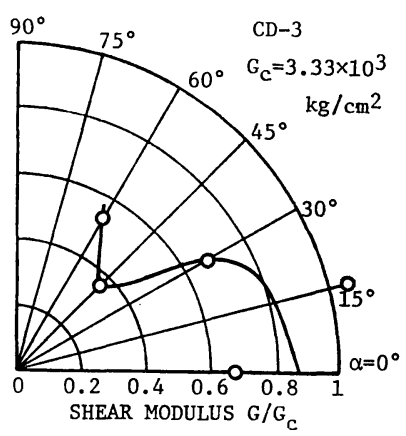

(b) $\mathrm{CD}-3$

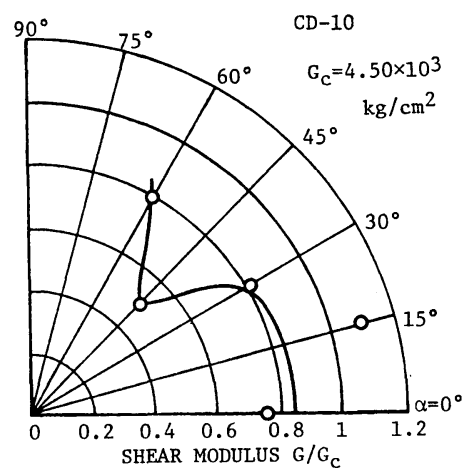

(e) $\mathrm{CD}-10$

図一12 せん断弾性係数 $G$ に及ぼす切断面の影響 \begin{tabular}{ll}
$90^{\circ}$ & \\
9 & $75^{\circ}$ \\
\hline
\end{tabular}

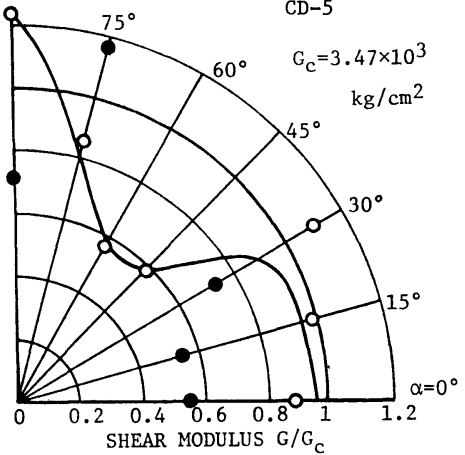

(c) $\mathrm{CD}-5$

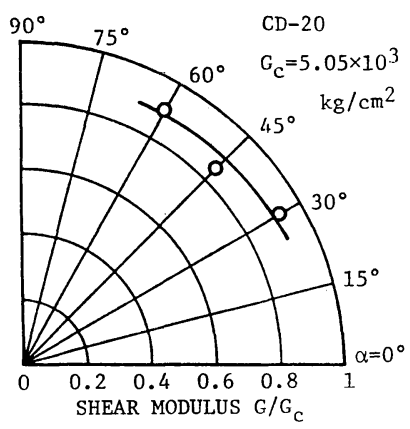

(f) $\quad$ CD-20

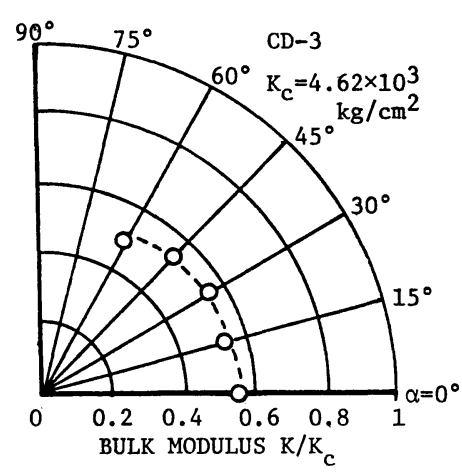

(b) $\mathrm{CD}-3$

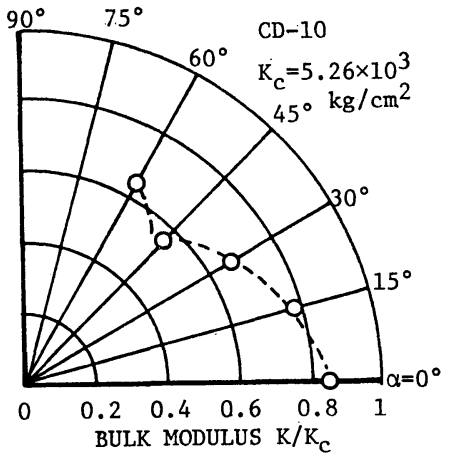

(e) $\mathrm{CD}-10$

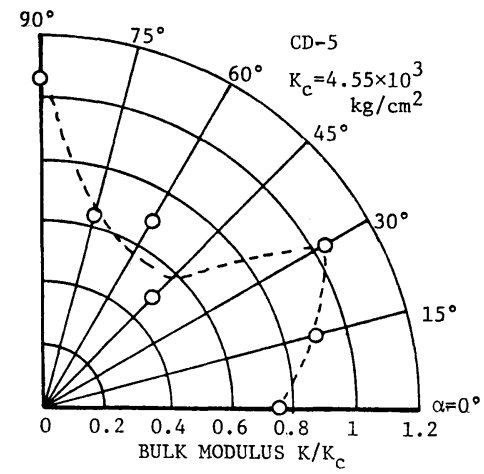

(c) $\mathrm{CE}-5$

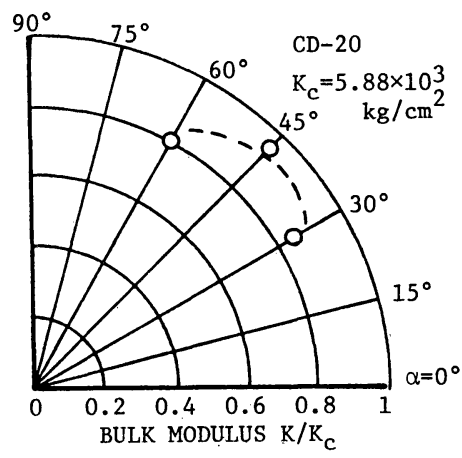

(f) $\mathrm{CD}-20$ 


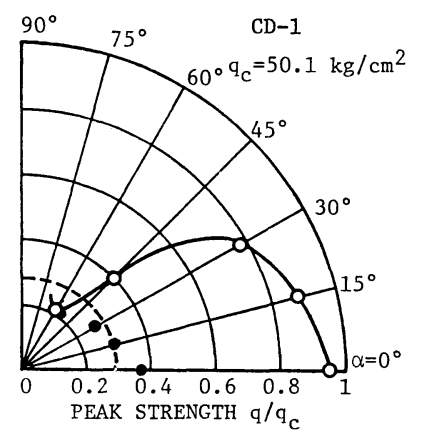

(a) $\mathrm{CD}-1$

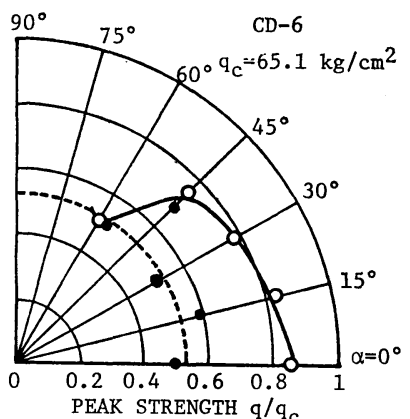

(d) $\mathrm{CD}-6$

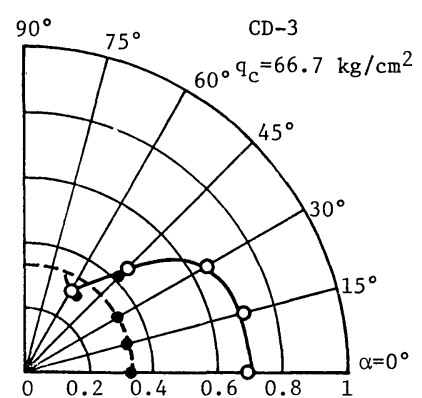

PEAK STRENGTH $\mathrm{q} / \mathrm{q}_{\mathrm{c}}$

(b) $\mathrm{CD}-3$

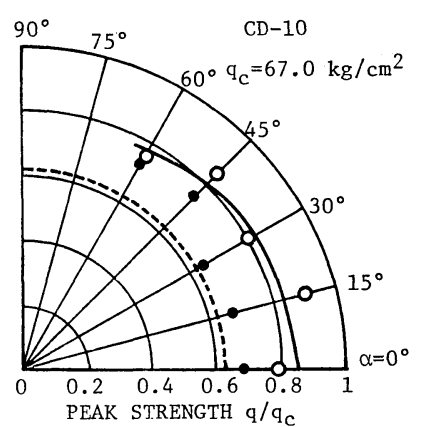

(e) $\mathrm{CD}-10$

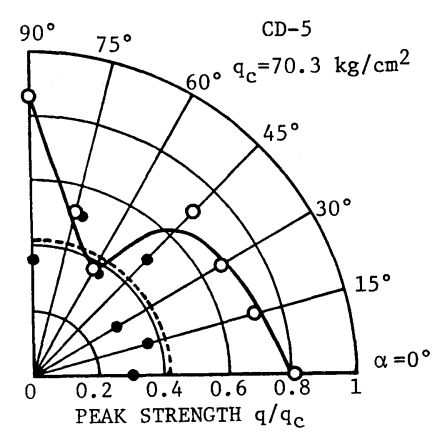

(c) $\mathrm{CD}-5$

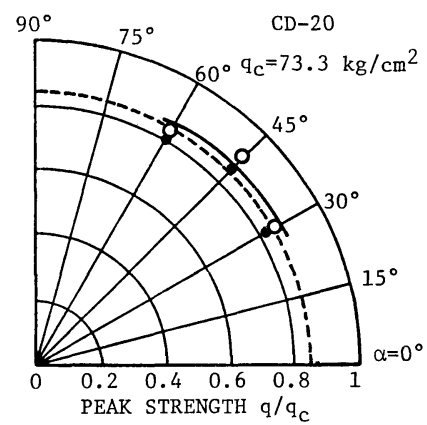

(f) $\mathrm{CD}-20$

図ー14最大ならびに残留強度に及ぼす切断面の影響

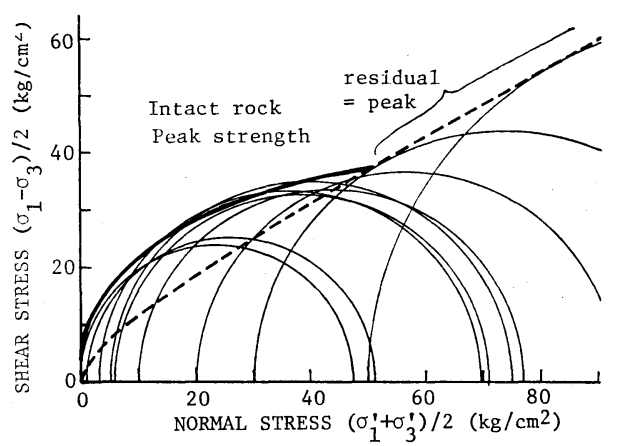

（a）最大強度

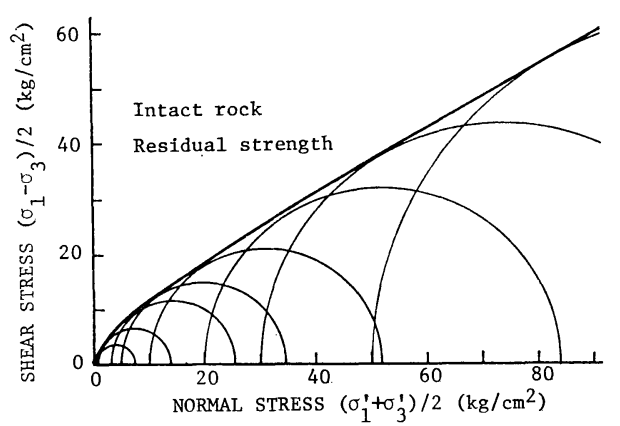

(b) 残留强度

図一15 intact rock $の$ Mohr の応力円と破壊包絡線

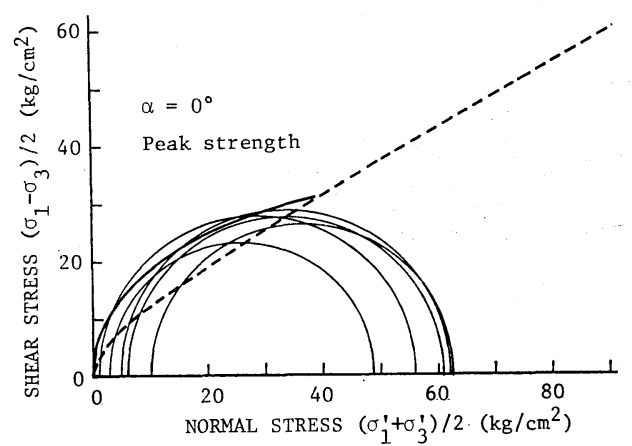

(a) $\alpha=0^{\circ}$

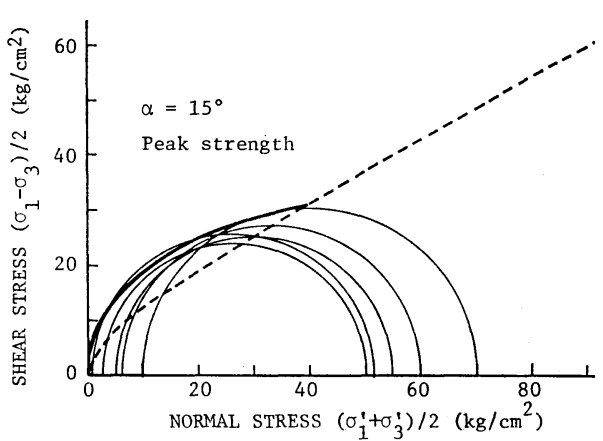

(b) $\alpha=15^{\circ}$ 


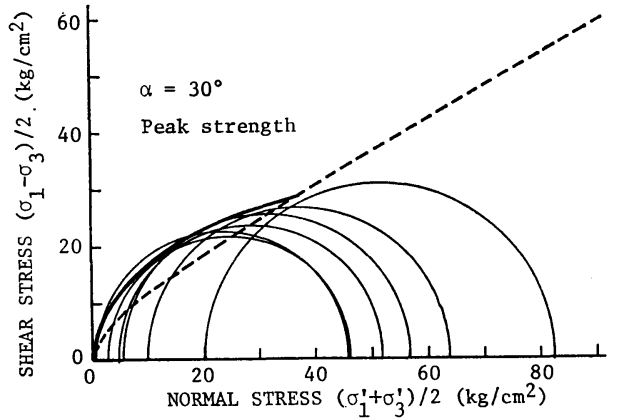

(c) $\alpha=30^{\circ}$

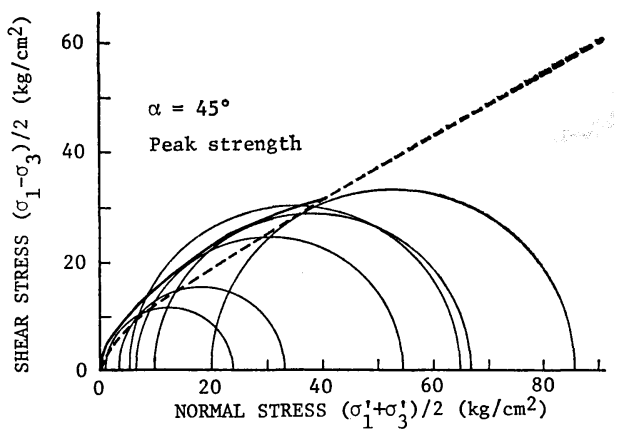

(d) $\alpha=45^{\circ}$

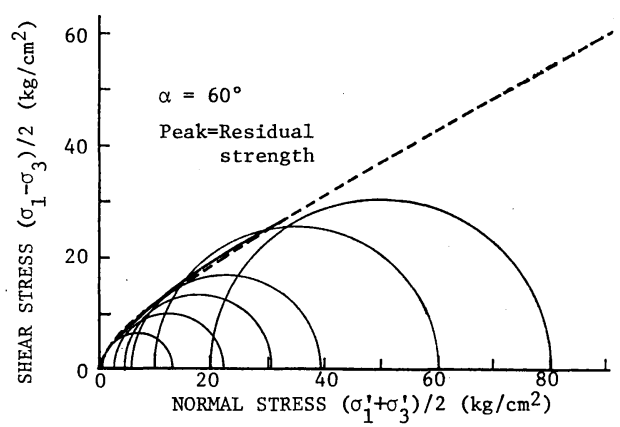

(e) $\alpha=60^{\circ}$

\section{図一16切断面をもつ供試体の最大強度に対する} Mohr の応力円と包絡線

図一15 (b) は残留強度に対する Mohr の応力円と包絡 線を示している. 図一15 (a) の点線は 図一15 (b) で求 まる残留強度の包絡線を示すが，先行履歷応力以上では 最大強度の包絡線と一致する. 図で明らかなように，最 大強度, 残留強度双方の破壊包絡線はともに曲線である から，直線で表される Mohr-Coulomb の破壊規準が厳 密には適用できない。

図一16 には $\alpha=0^{\circ}, 15^{\circ}, 30^{\circ}, 45^{\circ}, 60^{\circ}$ の切断面をもつ 供試体の最大強度に対するMohr の応力円と破壊包絡線 を実線で, 点線は図一15 (b) に与えた intact rock の残 留強度の破壊包絡線をそれぞれ示している．図において 破壊包絡線は曲線であって，切断面の角度が $45^{\circ} ， 60^{\circ}$ に対する破壊包絡線は点線で表される残留強度の包絡線
に漸近することが明らかである.

以上をまとめると，切断面を有する供試体の最大強度 に対する破壊包絡線は intact rock の最大強度の包絡線 と残留強度の包絡線の間に位置することがわかる。

\section{5. 不連続面を有する軟岩の破壊規準}

2.で述べたように，足立・小川は軟岩の破壊規準と して, Hobbs $\left.{ }^{9}\right)$ らが岩石質材料に対して提唱しているべ き関数形の破壊規準が応力間の条件式に，また，土質材 料の critical state に対して成立する体積ひずみが平均 有効応力の対数に比例するという関係式が強度と体積ひ ずみの間の条件式として適用できることを示し，新たに 軟岩の最大ならびに残留強度双方に対する破壊条件式を 提案した。

この破壊条件式が不連続面を含有する軟岩の破壊条件 式として適用できるかどうかを検討するため，図一17， 18 を準備した。

まず，破壊時の応力間に成立する関倸を調べてみる. 図一17 は切断面の角度ごとの最大強度 (白印) ならび に残留強度 (黒印) と平均有効応力の関係を両対数紙上 に求めたものである.多少のばらつきはあるが，最大強 度は切断面の角度によって勾配の異なる点線で示す直線 で表すことができ，残留強度は $\alpha=45^{\circ}$ を例外とするが， 切断面の有無や角度に関倸せず，実線で与える 1 本の直 線で表される。

したがって，式（1）、 (4) 1 ，破壊規準が不連続面を 有する軟岩にも適用できることが明らかである.すなわ ち最大強度定数 $\alpha_{P}, \beta_{P}$ は不連続面の角度によって変化 するが，残留強度定数 $\alpha_{R}, \beta_{R}$ は不連続面の有無や不連 続面の角度によらない材料定数として決定できることが 明らかである．さらに，図一1 で論じたように，不連続 面を有する軟岩の最大強度は図中に実線で与える intact rock の最大強度と残留強度の間に位置することが容易 に理解できる.

次に，破壊時に応力と体積ひずみがどのような関係に あるか検討してみる。図一18 は縦軸に体積ひずみ 横軸に平均有効応力 $\sigma_{m}{ }^{\prime}$ を対数にとり, 最大強度時（白 印）と残留強度時（黒印）の関係を与えている. 図中の 一点鎖線は等方圧密曲線，点線は低い側圧下に扮ける残 留強度状態線と高い側圧下での最大＝残留強度状態線で あって, intact rock に対して求められたものである ${ }^{4)}$. 有効側圧 $\sigma_{3}{ }^{\prime}=20 \mathrm{~kg} / \mathrm{cm}^{2}$ 以下の側圧で行った本研究に挍 いて, $\alpha=60^{\circ}$ の場合を除いて最大強度はほぼ等方圧密 曲線上で生じるが，残留強度は○印で囲んだ低側圧下の $\alpha=45^{\circ}, 60^{\circ}$ を例外として intact rock に対寸る次の条件 式で与えられる直線上にあることがわかる. 


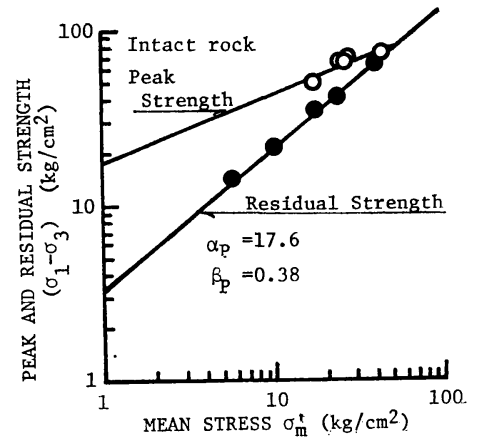

(a) intact rock

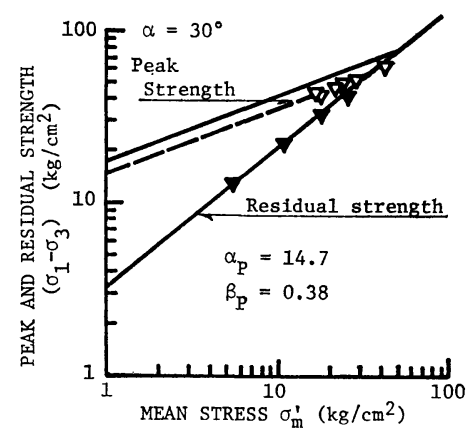

(d) $\alpha=30^{\circ}$

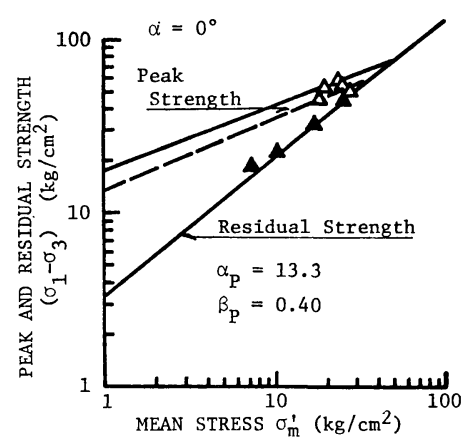

(b) $\alpha=0^{\circ}$

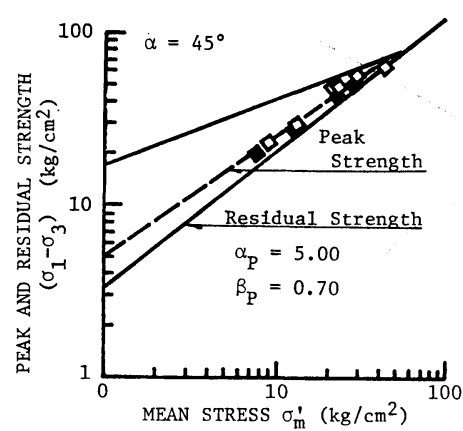

(e) $\alpha=45^{\circ}$

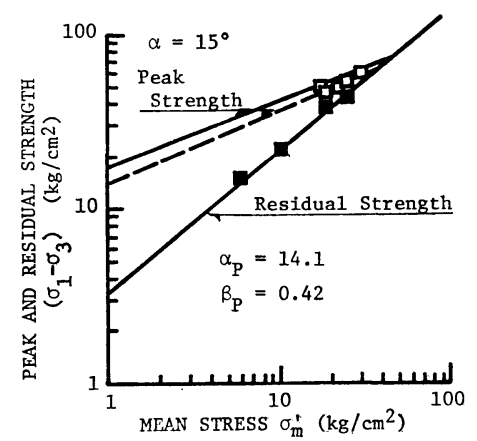

(c) $\alpha=15^{\circ}$

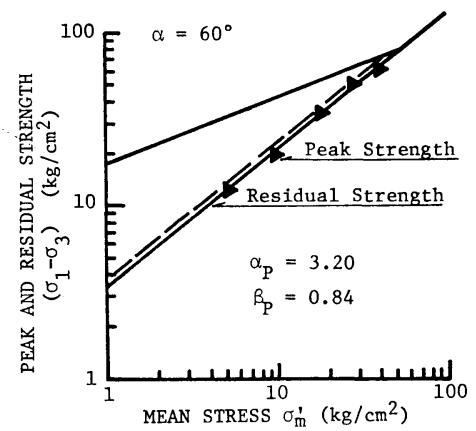

(f) $\alpha=60^{\circ}$

\section{図一17切断面をもつ供試体の最大強度と残留強度の破壊規準}

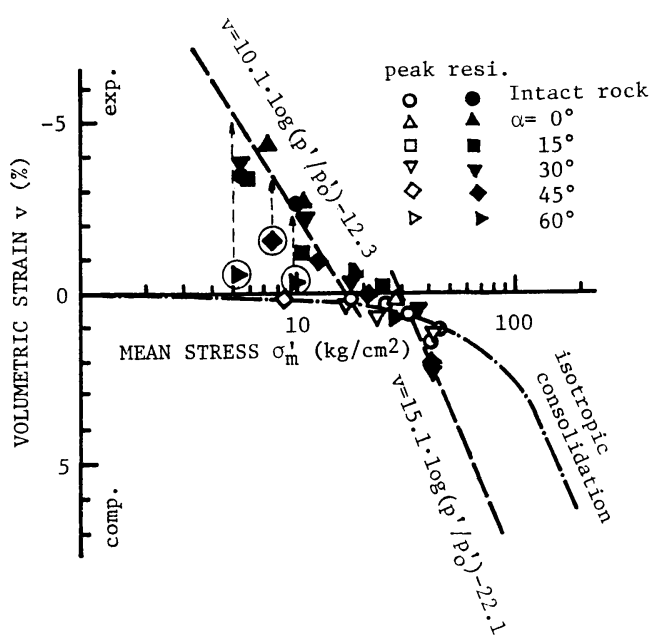

図一18切断面を有する供試体の最大ならびに残留強度時 の平均有効応力と体積ひずみ関係

$$
v=10.1 \log \left(p^{\prime} / p_{0}{ }^{\prime}\right)-12.3(\%)
$$

ここに, $p^{\prime}=\sigma_{m}{ }^{\prime}, p_{0}{ }^{\prime}=\sigma_{m 0}{ }^{\prime}=1 \mathrm{~kg} / \mathrm{cm}^{2}$ である.

低側圧下で, $\alpha=45^{\circ}, 60^{\circ}$ に対する残留強度時の状態 が条件式 (11) からはずれる理由を考察してみる. 図一 19 は CD-1 のせん断過程における平均有効応力と体積 変化の様子を示している. $\alpha=45^{\circ}, 60^{\circ}$ の場合は, 最終 到達点である残留強度時の体積変化が他の場合に比較し でさいこしは图一8 (b) に扔いても明らかである。术

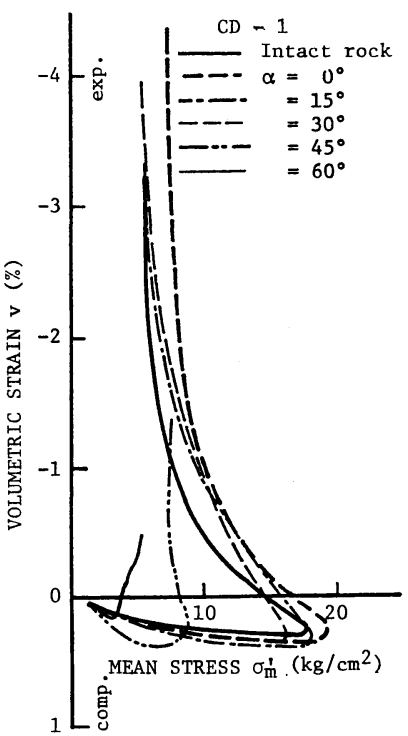

図一19 せん断過程の体積ひずみ-平均有効応力関係

なわち, $\alpha=45^{\circ}, 60^{\circ}$ では既存の切断面に沿うすべり破 壊であって, 他の場合のように顕著な体積膨張を伴わな いからである．換言すると, $\alpha=45^{\circ}, 60^{\circ}$ の場合は内部 構造が破壊され新たに破断面が生じる際の体積膨張もす でに終了した後の挙動に相当していると考えられる. このことを模式的に示すと図一20 のよ5になる.すな 才5, 尖験で求まる $\alpha=60^{\circ}$ の体積変化の軌跡 $\overrightarrow{\mathrm{OA}}$ \&, 


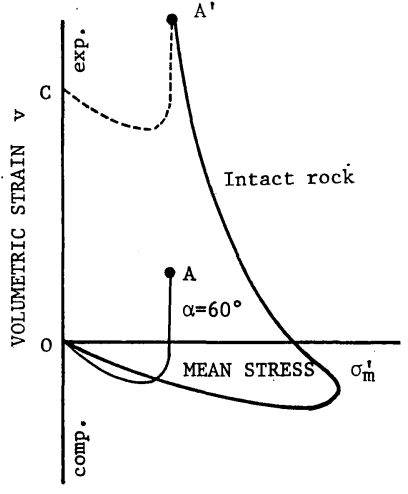

図一20 既存の切断面に沿う破壊時の ダイレイタンシーの考え方

実際は点線で表す軌跡 $\overrightarrow{\mathrm{CA}}^{\prime}$ に相当しており， $\mathrm{A}^{\prime}$ 点で intact rock の残留強度時の值と一致するという考え方 である.この考えによると，体積膨張量 $\overrightarrow{\mathrm{OC}}$ が新たに破 断面が生じるときのダイレイタンシー量である．CD-5 と CD-6 において破断面が生じた後で行った除荷-再載 荷試験により，この考えを検証でき，結果をみる限りに おいてはこの考え方が妥当である.

以上論じた破壊規準を地質分離面などの不連続面を含 む岩盤の解析に適用するためには，議論をさらに進める 必要がある.

一般的にいって，地盤材料の破壊規隻は図一17 のよ
らな応力の第 1 不変量である平均有効応力 $\sigma_{m}{ }^{\prime}$ を用いる よりは, 最大主応力 $\sigma_{1}{ }^{\prime}$ と最小主応力 $\sigma_{3}{ }^{\prime}$ の平均值 $\sigma_{n}{ }^{\prime}=$ $\left(\sigma_{1}{ }^{\prime}+\sigma_{3}{ }^{\prime}\right) / 2$ を用いて, $q=\left(\sigma_{1}{ }^{\prime}-\sigma_{3}{ }^{\prime}\right)$ との関係で与える 方が, 三次元応力場の問題への適用性のよいことが知ら れている. 図一21 は 図一17 の関係を $q / 2$ と $\sigma_{n}{ }^{\prime}$ の関 係として求めな掞したものである. 図より $q / 2$ と $\sigma_{n}{ }^{\prime}$ の 間にも $q$ と $\sigma_{m}{ }^{\prime}$ と同様の関係が成立することがわかり その関係は次式で与えられる.

最大強度に対して

$$
\left(q / 2 \sigma_{n 0}{ }^{\prime}\right)_{\text {peak }}=\alpha_{P} *\left(\sigma_{n}{ }^{\prime} / \sigma_{n 0}{ }^{\prime}\right)^{\beta_{P^{*}} .}
$$

残留強度に対して

$$
\left(q / 2 \sigma_{n 0}{ }^{\prime}\right)_{\text {residual }}=\alpha_{R}{ }^{*}\left(\sigma_{n}{ }^{\prime} / \sigma_{n 0}{ }^{\prime}\right)^{\beta_{R}{ }^{*} .}
$$

ここに, $\sigma_{n 0}{ }^{\prime}=1 \mathrm{~kg} / \mathrm{cm}^{2}$ である. 各切断面の角度に対す る強度定数 $\alpha_{P}^{*}, \beta_{P} *$ と $\alpha_{R}{ }^{*}, \beta_{R} *$ は図中にその值を 与えている。 な拉，図一21 (f) に洛角度に対して求め た式（12）を1つの図としてまとめてあり，不連続面を 有する供試体の最大強度は最大主応力作用面とのなす角 度 $\alpha$ にって, intact rock の最大強度と残留強度の間 に位置するといら図一1 の考え方を明らかに示してい る.

次になすべきことは式（12），(13）に含まれる強度定 数 $\alpha_{P}{ }^{*}, \beta_{P}^{*}, \alpha_{R}^{*}, \beta_{R}{ }^{*}$ と切断面の角度 $\alpha$ の関係を求 めることである. 図一22 はその関係を示している. $\alpha>$ $60^{\circ}$ に対しては CD-5 の場合の実験しか行っていない

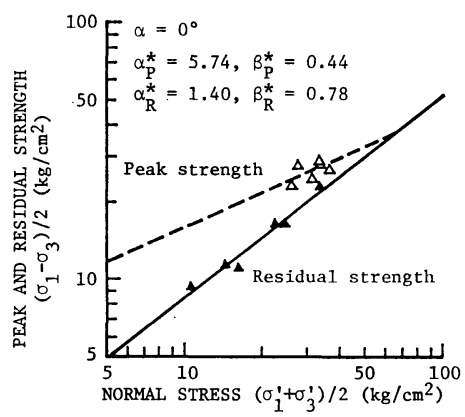

(a) $\alpha=0^{\circ}$

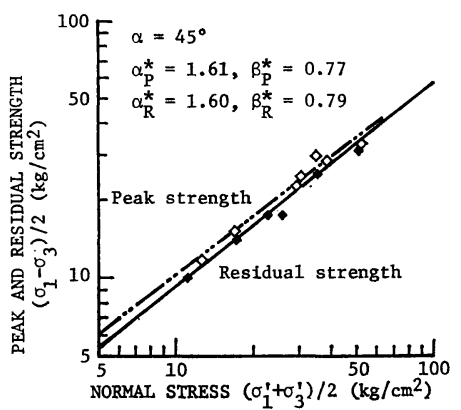

(d) $\alpha=45^{\circ}$

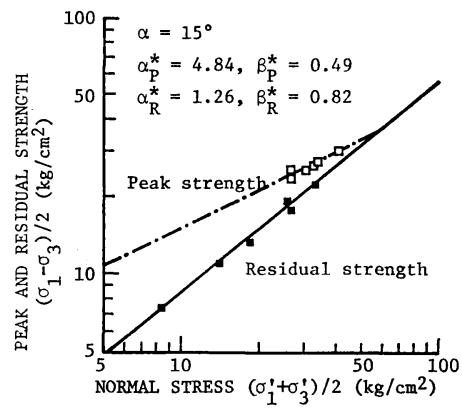

(b) $\alpha=15^{\circ}$

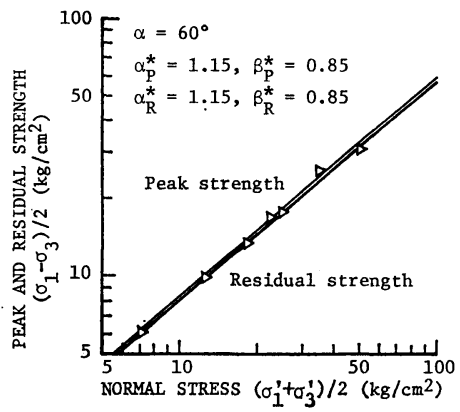

(e) $\alpha=60^{\circ}$

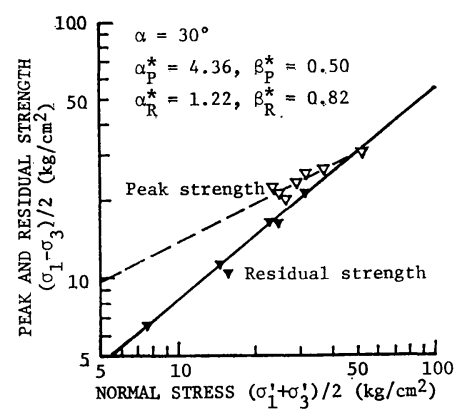

(c) $\alpha=30^{\circ}$

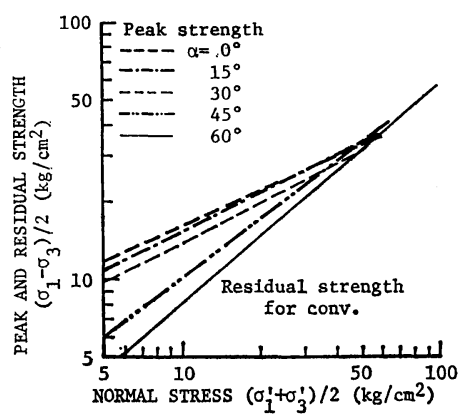

（f）総 括 因 


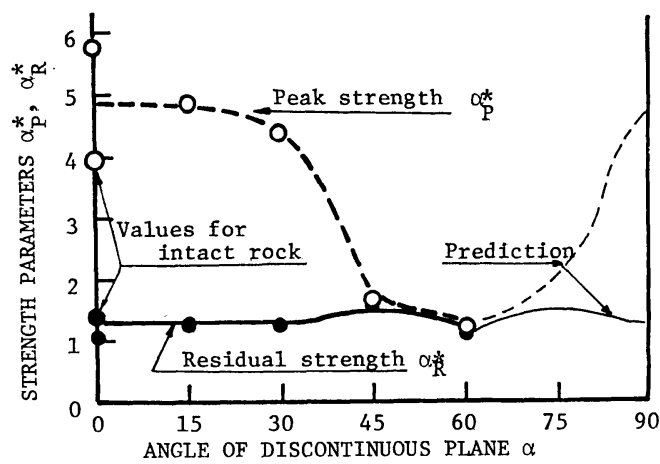

(a) $\alpha p^{*}, \alpha_{R}^{*}$

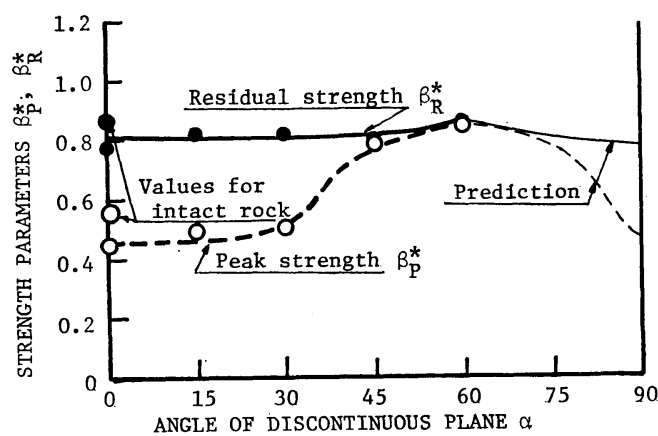

(b) $\beta P^{*}, \beta_{R}^{*}$

図一22 切断面の角度と強度定数の関係

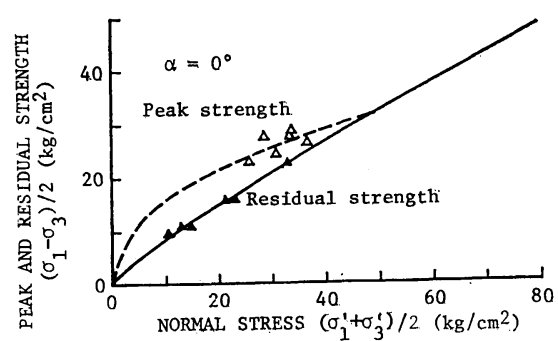

(a) $\alpha=0^{\circ}$

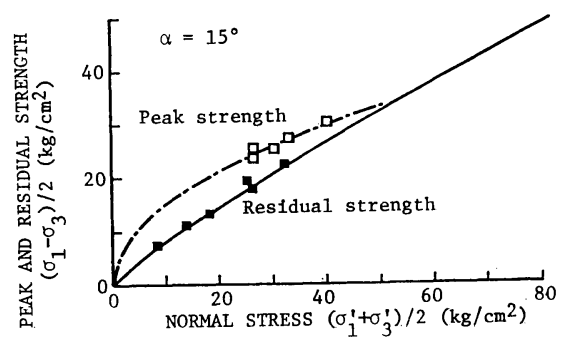

(b) $\alpha=15^{\circ}$

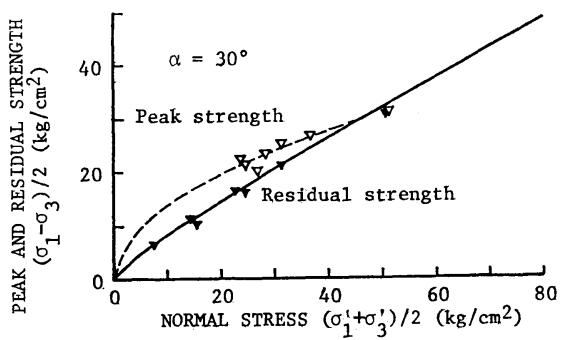

(c) $\alpha=30^{\circ}$

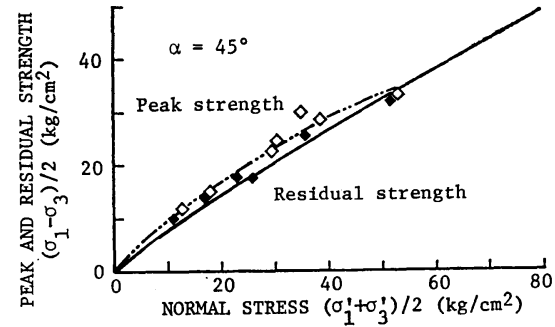

(d) $\alpha=45^{\circ}$

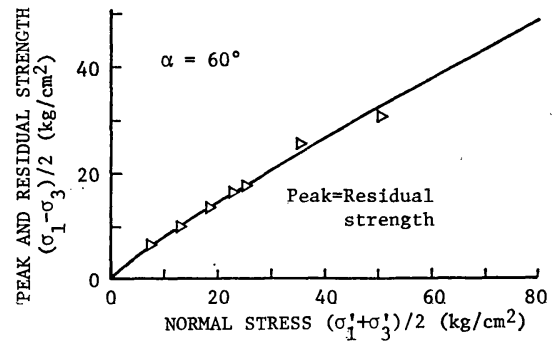

(e) $\alpha=60^{\circ}$

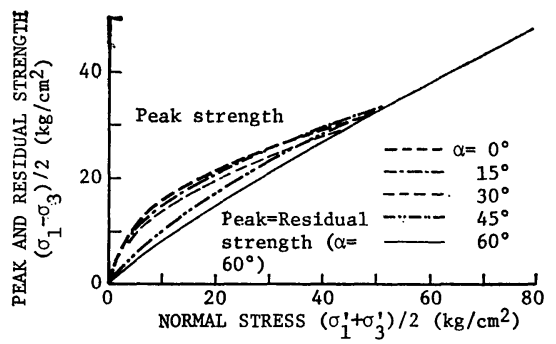

(f) 総 括 因

\section{图一23 切断面を有する供試体の破壊規準の適応性}

から，図一14 を勘案することで予測線として与えてい る.

最大強度定数 $\alpha_{P}^{*}$ は $\alpha=30^{\circ}$ までほぼ一定值をとり, $\alpha \doteqdot 60^{\circ}$ で最小値となる関数で表される.この関数形を 決定するには不連続面の角度とその面での応力を Mohr の応力円を用いて求め，そこですべるかどうかを判定す る Müller ら ${ }^{5)}$ Bray $^{12)}$ の考え方を準用する一方， $\alpha$ $>30^{\circ}$ をより細分した角度の切断面をもつ供試体に対し て実験を行う必要がある.

残留強度定数 $\alpha_{R}{ }^{*}$ は切断面の有無, 角度に関係せず, ほぼ一定値をとると考えてよい。

$\beta_{P}{ }^{*}$ は $\alpha_{P}{ }^{*}$ と同様 $\alpha=30^{\circ}$ までは一定值をとり, $\alpha \fallingdotseq 60^{\circ}$ で最大值を示す $\alpha$ の関数で表されるが, $\beta_{R}{ }^{*}$ は $\alpha$ に依存せず一定值をとると仮定できる. 寸なわち, 
$\alpha_{P} *=\alpha_{P} *(\alpha), \quad \beta_{P} *=\beta_{P} *(\alpha)$

$\alpha_{R}{ }^{*}=$ 一定 (材料定数),$\beta_{R}^{*}=$ 一定 (材料定数)

の関数形を求めると, 不連続面を含有する軟岩の破壊時 に応力間に成立する規準は確定され実際の解析に適用で きる. 先に述べたように, 関数形の決定は今後の課題で ある. また，破壊時の応力と体積ひずみ間に成立する条 件式について論じなかったが, 図一18に図一20の考え 方を適用することによって不連続面の角度を変数に用い 統一的に論ずる必要がある.

図一23 は図一21 で得られる強度定数を用い $q / 2 \sim \sigma_{n}{ }^{\prime}$ 関係として求まる破壊曲線と実験值を示したものであ る. 本研究で論じた破壊規準がこの程度に切断面を有す る軟岩の破壊時の応力状態を表現できることを示してい る.

地質分離面など不連続面を有する軟岩の力学挙動を, 切断面をあらかじめ与えた供試体を用いた実験によって 検討した. しかし，前述したとおり岩盤の解析に適用す るには強度定数 $\alpha_{P}^{*}, \beta_{P}^{*}$ の角度 $\alpha$ に関する関数形を決 定する必要がある.ここでは, 有限要素法を解析に利用 する場合を想定して，この成果を実際問題に適用する方 法について若干ふれておく.

対象とする岩盤内である方向に卓越する不連続面が存 在する場合には, ある領域 (要素) 内の最大主応力の作 用面と不連続面のなす角度 $\alpha$ がわかると, その領域（要 素）内の破壊は条件式（12）により規定される.したが って,この条件式を破壊規準として解析に組み込んでお けば各要素内で応力と不連続面との相互作用を勘案した 解を求めることができる. この際, 厳密には図一18 に 示す破壊時の応力一体積ひずみ条件式も同時に満足すべ きことはいうまでもない.

\section{6. 結 論}

地質分離面など不連続面や弱面が，軟岩からなる岩盤 の力学挙動に及ぼす影響を明らかにするため, 大谷石を 試料に選び問題を理想化して軸荷重作用面と種々の角度 $\alpha$ をもつ切断面をあらかじめ与えた円柱形供試体を用い て, 三軸圧縮試験を行い考察を加えた. この結果得られ た知見は以下のようである.

(1) 先行履歷応力以下の平均有効応力のもとでは, $\alpha$ が $45^{\circ}$ と $60^{\circ}$ を除く角度の切断面をもつ供試体は intact rock と同様, 顕著なひずみ硬化-軟化型の応力-ひ ずみ関係を示すがそのせん断過程で既存の切断面とは無 関係に新たな破断面を生じ, 体積膨張（ダイレイタンシ 一）を伴って破壊する. しかし， $\alpha=45^{\circ}$ と $60^{\circ}$ では既 存の切断面に沿うすべり破壊となり, 弾一完全塑性型に
近いか, 単調なひずみ硬化型の応力ーひずみ関係を示し 体積膨張度合はほかに比較して小さい.

（2）平均有効応力が先行履歴応力に近いか, それ以 上になると既存の切断面は力学挙動に影響を与えない.

(3) 軸差応力-偏差ひずみ関係の初期の接線勾配と して求めるせん断弾性係数 $G$ は切断面の影響を受け $\alpha=45^{\circ}$ で最小值となる. しかし, 平均有效応力〜体積 ひずみ関係から決定される体積弾性係数 $K$ は切断面の 影響をそれほど受けない，破断面が生じた後行った除荷 一再載荷過程で求まる弾性係数 $G, K$ は初期の $G, K$ に 比較して小さいが, オーダー的には変わらない。すなわ ち，不連続面を含む岩盤の弾性的性質は intact rock の それとそれほど異なるものではなく, intact rock の值の 40〜50\% 以上の值と考えてよい.

（4）平均有効応力が先行履歴応力以下であると, 最 大強度は切断面の角度 $\alpha$ により変化し， $\alpha=60^{\circ}$ で最小 值をとる. 他方, 残留強度は切断面の有無, 角度にほと んど影響されず intact rock の残留強度に等しいと考え てよい. また, 切断面を有する供試体の最大強度は intact rock の最大強度を上限值, 残留強度を下限值とす る範囲内にある.

（5）切断面を有する材料の最大強度, 残留強度とも 式 (12)，(13）で与えられるべき関数形の破壊条件式で 表される. 図一22 に示すように最大強度に対する強度 定数 $\alpha_{P} *, \beta_{P} *$ は切断面の角度 $\alpha$ の関数となるが, 残 留強度定数 $\alpha_{R}{ }^{*}, \beta_{R}{ }^{*}$ は $\alpha$ に関係せず一定值をとると 仮定できる.さらに破壊時の応力と体積ひずみの間にも 関係がある. すなわち, 平均有効応力が先行履歴応力以 下であれば, 最大強度状態は等方圧密曲線近傍にある. 他方, 残留強度状態は既存の切断面以外の破断面が新た に発生して破壊する場合には，intact rock に対する式 (11)の規準が適用できる.しかしながら既存の切断面に 沿らすべり破壊においては, 図一20 で論じたダイレイ タンシー量の補正を行うことで式 (11) の条件式を適用 できるが, 切断面の角度 $\alpha$ との関係などは未解決の問題 である。

本研究の成果に基づき, 不連続面や弱面を有する地盤 材料の力学挙動とそれを対象としたときの安定解析の考 え方について若干ふれておく.

不連続面や弱面が問題となる地盤材料には硬岩や軟岩 からなる岩盤や亀裂をもつ粘土（fissured clay）などが ある. 軟岩を含めて, このような材料は小さな供試体を 用いた強度試験であっても, 結果は非常にばらつくこと が知られている.この理由はサンプリングの巧拙や材料 の不均質性にもよるが, 潜在クラックとか欠陥の存在に よることが多いと考えられるままた，弱面を含んだ試料 
は供試体の整形も困難であり, 結果のばらつきを回避す る意味からも不連続面によって 2 分されないような健全 な供試体を選び試験に供するのが普通である。このため 岩石試験結果から岩盤の力学挙動を推定することは至難 の技とされ, 岩石試験の結果を用いる場合には力学定 数 (強度・変形係数) をどの程度減ずればよいかがおも な課題であった。

このような種々の問題に対して 2,3 私見を述べてみ る.

（1）不連続面や弱面を含む材料の強度試験を行う場 合, 図一8〜11 に示す応力ーひずみ関係は最大強度のみ ならず残留強度も決定できるものであることが必要であ る. また，図一7 の破壊形状を記録すれば応力ーひずみ 関係との関連によって弱面によるものか, 内部構造の破 壊によるものかを識別でき, かつ強度のばらつく理由を 確定できる.

（2）材料の残留強度は不連続面や弱面の有無に関係 せず，材料特有の物性である.また，その材料からなる 地盤（岩盤）の強度の下限值に相当する. したがって, 設計のための地盤の安定解析は下限値を求めるといら立 場からまず残留強度を用いて行う.ついでその結果を基 準にして, 上向きに不連続面や弱面の有無とその方向性 による強度増分を考慮すべきである.すなわち，従来の 岩石強度から下向きに岩盤強度を推定する方法を岩石と 岩盤双方の最下限值である残留強度を基準にするという 考え方に改めるべきである.

（3）（2）で論じた不連続面の有無とその方向性によ る残留強度からの強度の割增し量は, 種々の角度をもつ 切断面を与えた供試体を用いる実験を行うことによって 推定できる.

本研究は京都大学防災研究所地盤災害部門で, 小川 ${ }^{13)}$ が実験に着手し，林 ${ }^{14)} に よ り$ 継続された成果をまとめた ものである.日頃ご指導をいただいている柴田 徹教授に 謝意を表すとともに小川豊和君 (Univ. of Western Ontario）に御礼を申し上げる次第である.

\section{参考文 献}

1）赤井浩一・足立紀尚・西 好一：堆積軟岩（多孔質凝灰 岩) の弾-塑性挙動, 土木学会論文報告集, No. 271, pp. 83 95, 1978.

2）赤井浩一・足立紀尚・西 好一：堆積軟岩（多孔質凝灰 岩) の時間依存特性と構成式, 土木学会論文報告集, No. 282 , pp. $75 \sim 87,1979$.

3) Akai, K., T. Adachi and K. Fujimoto : Constitutive Equations for Geomechanical Materials Based on Elasto-Viscoplasticity, Proc. Specialty Session 9, 9th Int. Conf. on Soil Mech. and Foundation Eng., Tokyo, pp. 1 10, 1977.

4）足立紀尚・小川豊和：堆積軟岩の力学特性と破壊規準, 土木学会論文報告集, No. 295, pp. 51 63, 1980.

5) Müller, L. and F. Pacher : Modellversuche zur Klärung der Bruchgefahr, Rock Mechanics and Engineering Geology, Suppl. 2, pp. 7〜24, 1965.

6) Einstein, H.H., R.H. Nelson, R.W. Bruhn and R.C. Hirschfeld : Model Studies of Jointed-Rock Behavior, Proc. 11th Symp. on Rock Mech. (AIME), pp. 83 109, 1970.

7) Ladanyi, B. and G. Archambault : Simulation of Shear Behavior of a Jointed Rock Mass, Proc. 11th Symp. on Rock Mech. (AIME), pp. 105 125, 1970.

8) Einstein, H.H. and R.C. Hirschfeld : Model Studies on Mechanics of Jointed Rock, Proc. ASCE, SM 3, pp. 229 248, 1973.

9) Hobbs, D.W. : A Study of the Behavior of Broken Rock under Triaxial Compression and its Application to Mine Roadways, Int. J. Rock Mech. Minning Sci., Vol. 3, pp. 11 14, 1966.

10) Murrell, S.A.F. : The Effect of Triaxial Stress Systems on the Strength of Rocks at Atmospheric Temperatures, Geophys. J., Vol. 10, No. 3, pp. 231 281, 1966.

11）堀 正幸：三軸試験結果に及ぼす面積およびメンブレン 補正について, 土木学会関西支部年次学術講演会講演概 要集, p. III-15, 1978.

12) Bray, J.W. : A Study of Jointed and Fractured Rock, Parts I and II, Rock Mechanics and Engineering Geology, 5, No. 2, 3, 4, pp. $117 \sim 136$, pp. $197 \sim 216$, 1967.

13) Ogawa, T. : Mechanical Behavior of Soft Sedimentary Rock, Master Thesis, Kyoto Univ., 1978.

14）林 正之：軟岩の力学特性に及ぼす不連続面の影響につ いて, 卒業論文, 京都大学工学部, 1979.

(1979.9.19 · 受付) 